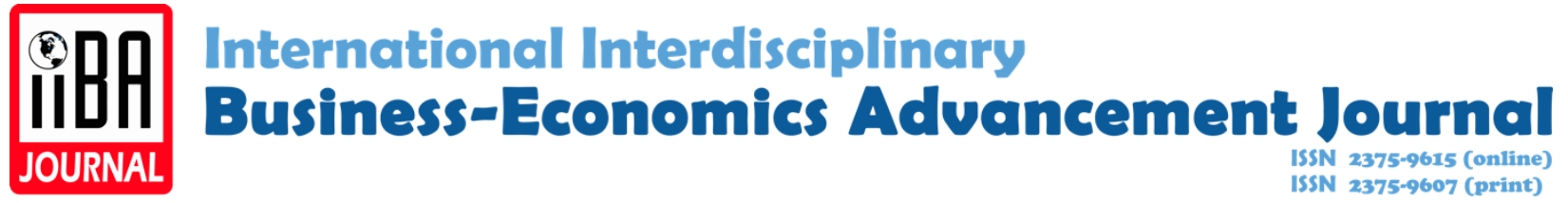

\title{
Quo vadis accounting and auditing in Turkey
}

Necdet Saglam

Anadolu University

\section{Recommended Citation}

Saglam, N. (2017). Quo vadis accounting and auditing in Turkey. International Interdisciplinary Business-

Economics Advancement Journal, 2(1), 27-41.

\section{Revisions}

Submission date: Apr. 5, 2015

1st Revision: Oct. 14, 2016

2nd Revision: Nov. 23, 2016

3rd Revision: Dec 15, 2016

Acceptance: Jan. 21, 2017 


\title{
Quo Vadis Accounting and Auditing in Turkey
}

\author{
Necdet Saglam \\ Faculties Faculty of Economics and Administrative Sciences \\ Anadolu University, Turkey \\ nsaglam@anadolu.edu.tr
}

\begin{abstract}
The main purpose of the research was to illustrate the history of accounting and auditing in Turkey. It is found that auditing has evolved through a number of stages. Current status of accounting and auditing profession in Turkey has been examined in this study. Recent issues and applications with regard to the statutory audits in Turkey has examined in detail. Related problems and solutions will also be discussed from a broad perspective of the professional standards.
\end{abstract}

Keywords: auditing, auditing in Turkey, accounting in Turkey

\section{Introduction}

Turkey has experienced prosperous economic growth over the last ten years, reaching 820.21 billion USD of GDP in 2013, against 230 billion USD in 2002. Similarly, national per capita income in Turkey tripled in the above-mentioned years from US $\$ 3,311$ to US \$10,946. Turkey is currently the seventeenth and seventh largest economy in the world and in Europe respectively. Thus, among European countries, Turkey is the fastest growing economy with a growth rate of $9.2 \%$ in 2010, 8.5\% in 2011 and $4.0 \%$ in 2013 and 2014 respectively. The annual growth rate of GDP in Turkey is on average 3.95 per cent over the period 1999 to 2014. Nevertheless, one of the G20 countries, Turkey is one of the top 10 emerging markets, global scale (Investment Support and Promotion Agency of Turkey, 2015).

Turkey's economic structure is still a complex mixture of industry and commerce along with a traditional agriculture sector. The private sector structure is financially strong and rapidly growing. Small and medium-sized enterprises (SMEs) constitute a vital part of the Turkish economy and account for $80 \%$ of the country's employment and $60 \%$ of its exports (Bell, 2014). It is ultimately the private sector with all its components that will lead to stable growth rates in the trade and investment figures. In Turkey, the private enterprises were predominantly familycontrolled. They are finding financial sources from on private sources as financial institutions and banks etc. According to the official figures of Ministry of Customs and Trade Company Statistic Bulletin (2014) there were 94,828 Joint Stock Companies and 713,861 Limited Liability Companies nationwide in June 2014 where a number of these companies are subject to statutory independent audit.

Turkey has applied for the membership of the European Union (EU) and now is one of the candidate countries for accession. Turkey's slow but continuous movement towards being granted a full membership status in the EU has created great momentum to adopt European 
business regulations and standards in the country. Turkey has already adopted International Standards on Auditing (ISA) and International Financial Reporting Standards (IFRS) for audits of the consolidated financial statements of all listed companies whose shares and securities are publicly traded. Turkey still has a complex and challenging market requiring adaptability and persistence.

This paper aims to analyze the development of auditing in the years in Turkey. It is found that auditing has evolved through a number of stages. It can be said that development of the auditing profession is related countries economic development. Auditing profession and auditing techniques are changing day by day and improving. Current status of accounting and auditing profession in Turkey has examined in this study. Recent issues and applications with regard to the statutory audits in Turkey has examined in detail. Related problems and solutions will also be discussed from a broad perspective of the professional standards.

\section{Literature Review}

Byrnes et al. (2012) studied Evolution of Auditing: From the Traditional Approach to the Future Audit in USA. The purpose of the study was to discuss the history of the traditional audit and the development of auditing. Matthews (2006), studied the history of the audit process in Britain: The Changing Audit Process in Britain from the Nineteenth Century to the Present Day, presenting that the characteristic features of the auditing industry are a diversity in practice based largely on the different types of clients the auditors serve. Teck-Heang and Azham (2008) studied the evolution of auditing: An analysis of the historical development.

The American Institute of Certified Public Accountants (AICPA) prepared a report on Evolution of Auditing: From the Traditional Approach to the Future Audit (AICPA, 2012). The purpose of this white paper was to discuss the evolution of auditing and the history of the traditional audit. Mikol (1993) studied the evolution of auditing and the independent auditor in France. Liu (2015) studied Study on the Auditing Theory of Socialism with Chinese Characteristics. Tomassini (2010) addresses the persisting development of auditing science by reckoning current megatrends in the auditing environment for the 1990s.

\section{History of the Audit Profession Worldwide}

Auditing and the auditing profession are quite old and it began with the start of this trade. Auditing was used mostly for the detection of fraud from ancient times until the late nineteenth century. It was done through extensive detailed examination of financial data. (Lee \& Azham, 1988). Anthropologists have found some records that are considered the first signs relating to auditing activities ever discovered as a proof of systematically performed audits during the Early Babylonian period. The first auditor's statement was put into use in 1289. The use of the term 'control' was discovered in some of the major civilization centers such as Venice, Milan, and Florence and in the 13th century. The first organization of auditors was established in Venice in 1581. The practice of modern audit and control activities began with the establishment of the modern trading entities during the Industrial Revolution (Saglam \& Yolcu, 2014).

Independent (external) auditing profession has emerged in the UK. In 1880, through the merger of five local accounting communities, Institute of Chartered Accountants in England and Wales (ICAEW) have been founded as the oldest professional constitution for the profession. In 1900, an act was issued to introduce limited liability companies with external audit requirements, to be 
performed by Chartered Accountants in the UK (Dubravka, 2016). The United States was enacted in 1934, the Capital Markets Law (Securities Exchange Act), enforcing public-listed companies to periodically publish their audited financial statements, assuring the importance of external audit.

In 1936, a professional committee within the American Institute of Certified Public Accountants (AICPA) began to focus on "the analysis of financial statements by independent public accountants". The SEC was authorized to publish the accounting standards and as well as auditors' oversight functions. In order to assist the SEC in ensuring that financial reports were prepared in accordance with Generally Accepted Accounting Principles (GAAP), accounting firms ultimately had to provide a certain level of assurance regarding audited financial information. Later, in October 1939, the AICPA published the Statement on Audit Procedure (SAP) No. 1, requiring the auditors to inspect the auditees' inventories and to confirm their trade receivables and payables externally. As a result, external auditors became responsible for carrying out the audit procedures independently, rather than simply relying upon the client management's verification routines. As a result of this application, inspection and audit-based auditing practices have become the norm for the profession. Manual audit procedures continued to be practiced exclusively even though, in the 1950s, computerized accounting information systems began to be used (Byrnes et al., 2012).

In 1978, the Auditing Standards Board (ASB) was formed to be in charge with the interpretation of the Generally Accepted Auditing Standards (GAAS) in the US. The ASB is now a subcommittee within the AICPA which assumes the responsibility to set the ground rules for auditors in order to determine on whether the information reported in the financial statements is reasonable and complies with the GAAP.

The International Auditing and Assurance Standards Board (IAASB) was established in March 1978. In 2003, the International Federation of Accountants (IFAC) agreed on a series of reforms aimed at further strengthening its standards-setting processes, including those of the International Organization for Standardization (IAASB), so that the standards have been more responsive to the public interest (The International Auditing, 2016). The IAASB is an independent standardization body that serves the public interest by setting high-quality international auditing standards, quality control, review exercises, and other related attestation services that are aimed at facilitating the convergence of global and national standards implemented in all parts of the world. In so doing, the IAASB strengthens the quality and consistency of professional practice around the world and builds public confidence in the auditing and assurance profession around the world. The ISAs are professional standards for the performance of audits of the financial information. These standards are issued by IFAC to the public through the IAASB.

\section{A Brief History of Accounting Practice in Turkey}

Until now, the accounting and auditing system have experienced significant development and evolutions, which have been summarized below, in Turkey.

Merdiven (Stairs) method for bookkeeping was used by the Ottomans between 14th and 19th century and was developed by the ones who wanted to shorten the procedure of bookkeeping. (Saglam \& Yolcu, 2014). Ottomans and Seljuk used siyakat writing and numbers in their records. In Seljuk and especially Ottoman records, siyakat writing based on Arabic alphabet was 
used. (Saglam \& Yolcu, 2014). Risale-i Felekkiyye (Kitab-us-Siyaqat) that was a state accounting book was written in 1363. It explains accounting books, account types, and some principles about Ottoman state accounting (Kamu Gözetimi Kurumu [KGK], 2014).

The first Code of Commerce adopted in 1850 and translated from French law. This law has structured the first accounting rules in Turkey. It was revised in 1926, prepared with extensive reference to the legislation of the various countries. In the law, there were two main classification for books and they were optional books and mandatory books. Ledger, Cash Book, Draft Book, and Promissory Notes Book, Book for Merchandise and Goods and Invoice Book were classified as Optional Books. The attestation need was not for these books. The system of double entry adapted. This code also regulates accounting practices (KGK, 2014).

The General Accounting Law No. 1050 was adopted in 1927 for governmental accounting. The Law established cash based accounting system for the governmental institutions. The purpose of recording and reporting were mainly the results of the budget applications, somewhat outside the accounting logic, structurally. This law regulated the accounting system in government. It was not accrual accounting base that's why it did not affect the private sector and the accountants (A Public Accounting Law, 1927).

Legal regulations affected the century were made between the years $1926-1930$. This important development was conducted with the acceptance of three important tax laws (Income Tax Law of 1926, Excise Duty Law of 1927, Consuming Tax Law of 1930). Taxes were conducted with declaration statements. This situation made double entry method and financial auditing practices important. Commercial state enterprises were established between the years 1930 and 1940, which brought forward subjects like, tax based accounting practices, tax auditing and education of accountants. It is observed that accounting profession started to be used in big cities at the end of 1930s. (Güvemli, Aytulun, \& Şişman, 2012)

It was made to create a general accounting plan for accounting applications of state economic enterprises (SEE), but it failed in the 1930s. The period 1950-1960 was the phase of the first efforts in the direction of more liberalized economy. The Tax Procedure Law (TPL, in 1950 and the new Commercial Code of 1956 came into effect, following contemporary economic developments. In 1960, a start was made to represent a consistent accounting system to be used in SEEs that guided the development of commerce, industry and accounting (World Bank, 2007). In 1972, the SEE's began to apply uniform accounting system.

The TPL has become the most effective regulation on accounting and financial reporting. TPL has provisions relating to undertakings which cover the determination of the tax base, as well as provisions relating to accounting, record keeping, documentation principles and financial statements and the existence of effective penalties in the event of failure to comply with these provisions. It was done for the purpose of determining the tax base (Balsari \& Varan, 2014).

The incentives were adapted to the private sector and foreign investment between 1950 and 1960. The economic system was influenced by the American system and its influence was also felt in the curriculum of academies, particularly in the field of business and accounting (KGK, 2014). 
The Capital Market Law (No. 2499) published 1981. The purpose of the Act with a view to ensuring effective and widespread public participation in the development of the capital market. (Capital Markets Board of Turkey [SPK], 2012). In 1984, the Law of the Istanbul Stock Exchange (IMKB and now BIST) decreed. IMKB began operating fully in 1986. The increase in foreign investment and progress in the development of accounting and auditing standards were objectives of the law. The first accounting regulation (Communiqué X1 No: 1) that related financial statements of listed companies adopted by the Capital Markets Board of Turkey at 1989.

The Communiqué of Accounting System Implementation (Turkish National GAAP) was prepared by the academics and others and was adopted by the Ministry of Finance in 1993. It establishes the accounting and reporting principles and the uniform chart of accounts. It was generally consistent with the 4th Directive numbered 78/660/EEC. Under this system all enterprises except banks and other financial institutions in Turkey are obliged keeping books on the basis of Balance Sheet both in the private and public sector (KGK, 2014).

On November 15, 2003, SPK, issued Communiqué X1/25, effective from January 1, 2005. It covers all IAS, IFRS and IFRIC interpretations and to close the existing differences between SPK requirements and IFRS. The communiqué X1/25 is required in respect of all listed companies. Other publicly-held companies do not follow the Communiqué. "Besides the regulations made by SPK, in accounting practices tax laws have effected and accounting has been practiced for the purpose of correct determination of the tax base rather than for providing relevant financial information" (Capital Market Board of Turkey, 2012).

In September 2008 the SPK issued Communiqué Serial: XI, No: 29 on the "Principles Regarding Financial reporting in Capital Markets". The European Union adopted IFRS for listed companies. In EU process in Turkey with Communiqué Serial: XI, No: 29, listed companies started to prepare their financial statements in accordance with IFRS (Capital Market Board of Turkey, 2012).

Turkish Accounting Standards Board (TASB) was established at 1999 by Law No: 4487 for building and publishing accounting standards to make accounting standards fully compliant with IFRS. TASB was established as a public legal entity and it was holding administrative and financial autonomy. It was necessary that the accounting and financial reporting practices converge with the qualified financial information needs of the companies (Gucenme, Isseveroglu, \& Ertan, 2011).

TASB has published Turkish Accounting Standards (TAS) in the Official Gazette with guidance of the principle of the official translation procedure which set out by the IFAC. After the establishment of TASB, related organizations as SPK, Banking Regulation and Supervision Agency Energy Market Regulatory Authority put TAS into practice by displacing their accounting by-laws and communiqués (KGK, 2014).

With the increasing globalization of the volume of investment and international capital markets to access the financial resources needed to ensure high quality financial information companies operating in Turkey. In addition, internationally recognized and reliable financial information is also important and necessary for investors. Turkey has candidacy for European Union 
membership and has to harmonize EU Acquis (IFRS) (KGK, 2014). The regulations on accounting practices in Turkey are similar to the EU Acquis. Publishing the Turkish Commercial Code (TCC 6102) in 2012, all companies have to apply accounting rules set by Public Oversight, Accounting and Auditing Standards Board of Turkey, (KGK's Organization and Responsibilities Decree Law numbered 660) shortly known as KGK, is authorized to determine scope of the application of TAS. They are fully complying with IFRS. KGK has made mandatory to apply TAS in EU process for public interest entities and some large-scale companies. Other entities will continue using Communiqué of Accounting System Implementation.

As seen above accounting \& auditing requirements were developed by each agency (SPK, the tax authorities etc.) depending on their own needs.

Issuing TCC, it has become the most important development about IFRS in Turkey. TCC broadens the application scope of IFRS. With TCC TASB had become the sole authority for setting accounting standards. KGK established in order to ensure more effective accounting, auditing and public oversight system in Turkey, and TASB has been displaced. The aim was to harmonize Directive 2006/43 / EC with the authority to determine auditing standards, to authorize independent audit firms and to oversee the activities and performance of independent auditors to ensure the uniform implementation, necessary confidence and quality in the area of independent audit. The KGK has the authority to:

- "set and issue Turkish Accounting Standards compliant with international accounting standards;

- to ensure uniformity, high quality and confidence in statutory audits;

- set the auditing standards;

- authorize independent auditors and independent audit firms; and

- inspect their audits and perform public oversight in the field of statutory audits" (IFRS Foundation, 2016, p. 1).

All big companies and other companies under control of SPK regulations have to present their legal and consolidated financial statements in accordance with TAS that is based on, and corresponds to, IFRS.

There are 41 Turkish Accounting/Financial Reporting Standards (TAS/TFRS) and 22 TAS/TFRS Interpretations which are in full compliance with IFRSs and they are updated regularly with IFRSs changes. In Turkey listed companies and capital market institutions; banks, leasing, factoring and financing companies; insurance, reinsurance companies and pension companies have been applying TFRSs (Financial Stability Board, 2014). Additionally, certain companies that is obliged to external audit are required to apply the TAS/TFRS.

As noted above, in Turkey, with the regulations made by KGK, accounting practices for informing the public and related parties were included on the agenda. Besides the regulations of the KGK, accounting practices have been effected and directed by tax laws and accounting has been practiced determine the tax base in a correct way instead of providing relevant financial information. In the regulation in Turkey all companies in accounting practice has led to the preparation of more than one financial statement for a single enterprise such as the "commercial statement" prepared in accordance with the TCC (the statement prepared in line with the KGK's 
requirements) and the "financial statement" prepared in accordance with the tax laws. It has been failure to ensure a standardization for uniform financial statements covering all companies. Additionally as seen above according TPL financial accounting is heavily influenced by tax provisions. In fact, financial statements must meet the needs of tax authorities.

The "Communiqué on Public Disclosure Platform" (PDP) regulates procedures for the preparation and disclosure of financial reports to the PDP. PDP is an electronic system whereby electronically signed notifications required by the capital markets and BIST regulations are publicly disclosed. The system covers more than 600 companies, 17 exchange-traded funds, 479 mutual funds, 236 pension funds and 2,600 users throughout Turkey (Public Disclosure Platform, 2016).

According World Bank Country report "International investors and rating agencies assess the overall transparency and disclosure levels of Turkey's top companies as "unsatisfactory" and, in general, bankers do not feel they can "trust" the financial statements presented by prospective borrowers due to rampant "problems of informality" (World Bank, 2007).

\section{Accounting Profession in Turkey}

The accounting profession in Turkey was well organized after 1990 and the development has been in the 19th century (World Bank, 2007). The accounting profession had occurred in big cities in 1930s. There were some initiative in the government to accept a law for accounting profession, but it was failed. The civil society association of Turkey had started to work the area of accounting in 1942 by academics and state supervisory bodies of a group of senior managers. İn 1967 they created the Expert Accountants Association of Turkey (Arikan \& Toraman, 2007; KGK, 2014).

In 1989 the Law (3568) adopted establishing the Union of Certified Public Accountants and Sworn in Certified Public Accountants of Turkey (TÜRMOB) (Arikan \& Toraman, 2007). The objective of Law of 3568 is to provide efficient and better auditing and accountancy services in Turkey. It sets the qualifications of accountants to be a member of the profession and the organizational setup of the accounting profession. Accountancy services stratified the profession as seen at Table: 1 in Turkey (TÜRMOB, 2016a) there are three accountant groups. They are the followings:

-Independent Accountant (IA): of which there are currently 9.628, may provide bookkeeping services; prepare financial statements and tax declarations. They cannot conduct any audits. This profession is closed to new entrants to the amendment made in the law no 5786 at 26.07.2008.

-Certified Public Accountant (CPA): numbering 89.498 may conduct general audits but not tax audits and provide consulting services in addition to all the services provided by IAs.

-Sworn-in Certified Public Accountant (Sworn-in CPA): numbering 4.708, may conduct tax audits and "certify" the tax financial statements and tax returns in addition to all the services provided by CPAs except bookkeeping. Sworn-in CPAs have joint responsibility with the audited company for errors and misstatements in the financial statements they have certified. 
Table 1: Numbers of Profession in Turkey (November 2016)

\begin{tabular}{lrrrrr}
\hline Professional Title & Total & Male & Female & Independent & Dependent \\
\hline IA & 9.628 & 7.978 & 1.65 & 4.669 & 4.959 \\
CPA & 89.498 & 63.38 & 26.118 & 48.151 & 41.347 \\
Sworn-in CPA & 4.708 & 4.35 & 358 & 2.548 & 2.16 \\
TOTAL & 103.834 & 75.708 & 28.126 & 55.368 & 48.466 \\
\hline
\end{tabular}

Source: TÜRMOB, 2016a

As seen at the table 103.834 the professional members are working in different sectors and 28.126 of them is female.

After adopting the law 3568, it has been important for Turkey accounting profession, accountancy education and training. It takes time being an accountant and it is very difficult. After graduation of university (have at least a BA or post-graduate degree in Law, Economics, Business Administration, Accounting, Banking, Public Administration or Political Science) a candidate of accountant has to pass entry exam which is organized by TÜRMOB. Each semester approximately 15,000 candidates enter the examination to enter and the success rate are around $15 \%$. TÜRMOB organize in 3 annual exams in a year. The candidates that passed exam have to make three years' practical training under supervision or control of either a CPA or a Sworn-in CPA. After training, they have to pass the professional CPA exams; and finally have CPA certificate that provide by TÜRMOB (TÜRMOB, 2016b).

According the 3568 law, CPA can give services to enterprises and business; to keep books; prepare the financial statements, tax returns and other relevant documents in compliance with relevant legislation. They can establish and improve accounting systems, to analysis and audit etc.

It is required that having at least 10 years of work experience as a CPA to have a license for "Sworn-in CPA" and to be succeed in the proficiency examinations. Sworn-in CPAs does not provide book keeping services. They are authorized by the public officials of the Revenues Directorate of the Ministry of Finance to approve financial and tax statements.

TÜRMOB's Education and Training Centre (TESMER) was founded in 1992. Its duty is to develop educational programs for improving and maintaining the professional competencies of its members, to develop and implement the practical experience programs to support the prequalification training and to ensure the training, supervision and the proficiency test for the qualified intermediate staff (TÜRMOB, 2016b). According to World Bank, the accounting profession will need to experience expanded education and training because of the complexities of IFRS, ISA, and the requirements of the EU acquis (World Bank, 2007).

CPA in Turkey usually do the work required by tax laws and social security law and it takes the majority of their time. Each month, they prepare VAT return, withholding tax return, social security declarations for the enterprises to give governmental authorities. That is the majority of their jobs. In addition, they give an income / corporation tax declarations in every three months for the enterprises. Therefore they do not have enough time to prepare reports for the business owner. 


\section{External Auditing in Turkey}

Auditing has been so audit of government accounts during the Ottoman period. At Ottoman period there were the auditors in the public sector. The auditing profession began to develop in the last century in Turkey.

The market economy began to develop after 1980 in Turkey. The auditor of a function is directly related to the market economy develops. In 1982 with SPK independent auditing has begun in Turkey. SPK developed its own standards of external auditing for companies listed on the ISE. (Capital Market Board of Turkey, 2012) The Law of Istanbul Stock Exchange (IMKB - now BIST) enacted in 1984. Increasing in foreign investments and increasing in joint ventures and foreign trade advanced the development of the accounting and auditing standards in Turkey. The 'Big Eight' accounting firms has been worked in Turkey. The banks and creditor demanded from entities' audited financial statements conformity of IFRS that's why large private enterprises started to report their financial statements in accordance with the IASs and national reporting requirements. In 1980s, the financial statements began to be audited and disclosed according to the IASs although the commercial books were kept by tax basis (Capital Market Board of Turkey, 2012).

The first auditing regulation in capital markets was made by SPK and the "Regulations on External Auditing in Capital Market" in 1987. In the Communiqués the basic principles and rules related with auditing were arranged. According SPK all listed companies' statements should audit by independent auditors and disclosed to the public (Capital Market Board of Turkey, 2012).

SPK adapt the independent auditing standards in the capital market (communiqué Serial: X, No: 22) was prepared in accordance with ISAs in 2006. (Capital Market Board of Turkey, 2012) The purpose of this Communiqué was to establish the standards, principles and methods criterion for the audit firms that will conduct statutory audits in the capital markets. SPK may oversight activities of those firms and report the results of quality control reviews and audit activities. This was the most comprehensive regulation on auditing in Turkey (Financial Stability Board, 2014).

Because of the global scandals in the USA and EU, SPK regulated some additional regulations in the area of independent auditing that have some similarities to the Sarbanes Oxley Act. They are such as restricting other services from auditing activities, a compulsory rotation period for audit partners and a requirement for an internal audit committee (United Nations Conference on Trade and Development, 2012).

With respect to independent audit liability, listed companies are subject to the principles to which companies whose capital market instruments carry similar features and/or are traded on the same market/platform of the stock exchange are subject. Financial statements must be independently audited in accordance with the principles envisaged by the ISA. Independent audit shall be carried out by the independent auditors listed in the Board's authorized organizations. The Board may request that a statement is made to the effect that features including quality control, recruitment, training, and so forth are in harmony with those of the companies included in the Board's list, for approval. 
In Turkey, several agencies and institutions, in particular SPK and Banking Regulation and Supervision Agency (BDDK) regulated auditing and because of this independent audit has had a fragmented structure. Other authorities which made regulations in audit field in specific institutions include; Turkish Treasury for insurance companies, Energy Market Regulatory Authority (EPDK) for energy companies.

Auditing of the banks is considered as regulated through based on Banking Law No. 5411. Articles 15, 33 and 39 of the Law require that the financial statements submitted to the shareholders should be audited by an independent audit firm approved by the BDDK. BDDK is responsible for the regulation and supervision of banking system in Turkey. BDDK has the authority over the inspection of statutory auditors within banking sector. BDDK may set additional criterion for the audit firms that will conduct statutory audits in the banking sector and may oversight activities of those firms and BDDK shall report the results of quality control reviews and inspection activities to the $\mathrm{KGK}$ (KGK, 2014).

Article 39 of the Insurance Audit Law No. 7397 is related to conduct audits at insurance companies. Under secretariat of Treasury has regulated "Regulations on Auditing of Insurance and Re-assurance Companies by External Audit Firms" of the Ministry of State. The Regulation on "Conduct of Independent Audit in Insurance and Reinsurance Companies" and in the Regulation on "Principles Applicable to Independent Audit of Insurance Companies" a September 2003 (World Bank, 2007).

The "Regulations on Auditing of Real and Legal Entities Operating in Energy Market by Audit Firms" adopted by the Energy Market Regulatory Authority. It was on auditing of activities and financial statements in energy market.

Audited organizations and numbers are given in the table below at Capital Market of Turkey between 2004 -2014 (Capital Market Board of Turkey, 2012).

Table 2: Audited organizations in Turkey

\begin{tabular}{lrrrrrrrrrrr}
\hline & $\mathbf{2 0 0 4}$ & $\mathbf{2 0 0 5}$ & $\mathbf{2 0 0 6}$ & $\mathbf{2 0 0 7}$ & $\mathbf{2 0 0 8}$ & $\mathbf{2 0 0 9}$ & $\mathbf{2 0 1 0}$ & $\mathbf{2 0 1 1}$ & $\mathbf{2 0 1 2}$ & $\mathbf{2 0 1 3}$ & $\mathbf{2 0 1 4}$ \\
\hline Intermediaries & 154 & 149 & 145 & 145 & 145 & 144 & 144 & 140 & 141 & 141 & 140 \\
Public Companies & 591 & 588 & 561 & 575 & 520 & 499 & 512 & 575 & 553 & 557 & 534 \\
Investment Trusts & 34 & 37 & 43 & 48 & 50 & 49 & 54 & 53 & 47 & 48 & 54 \\
Investment Funds & 381 & 434 & 451 & 461 & 541 & 523 & 695 & 757 & 781 & 743 & 746 \\
Pension company & 11 & 11 & 11 & 11 & 12 & 13 & 13 & 15 & 18 & 17 & 19 \\
Real Estate Appraisal & 0 & 0 & 13 & 26 & 50 & 63 & 82 & 113 & 123 & 130 & 130 \\
Companies & & & & & & & & & & & \\
Portfolio Management & 21 & 19 & 18 & 19 & 23 & 23 & 28 & 31 & 35 & 40 & 41 \\
Companies & 1 & 5 & 7 & 8 & 8 & 9 & 9 & 9 & 10 & 10 & 9 \\
Rating Agencies & $\mathbf{1 1 9 3}$ & $\mathbf{1 2 4 3}$ & $\mathbf{1 2 4 9}$ & $\mathbf{1 2 9 3}$ & $\mathbf{1 3 4 9}$ & $\mathbf{1 3 2 3}$ & $\mathbf{1 5 3 7}$ & $\mathbf{1 6 9 3}$ & $\mathbf{1 7 0 8}$ & $\mathbf{1 6 8 6}$ & $\mathbf{1 6 7 3}$ \\
Total & 83 & 91 & 94 & 98 & 97 & 95 & 92 & 92 & 92 & 92 & 93 \\
Independent Auditing & & & & & & & & & & &
\end{tabular}

Source: Capital Market Board of Turkey, 2012

At 2014 total 588 Public Companies (including investment trusts) are 422 Companies listed on the BIST and 166 Companies Non-Listed on the BIST. Total 746 of Investment Funds are Securities Mutual Funds 268, Pension Mutual Funds 247, Exchange Traded Funds 18, Hedge Funds 36, Foreign Mutual Funds 84, Protected Funds 76 and Guaranteed Funds 17. Total 140 of 
Intermediaries are Intermediary Institutions 98 and Banks 42. Total 54 0f Investment Trusts are Securities Investment Trusts 11, Real Estate Investment Trust 31and Venture Capital Investment Trust 12.

Another audit way in Turkey is the tax audits. According to The Tax Procedural Code auditing of tax-based financial statements must be done by a Sworn-in CPA if the company exceeds one of the two following size thresholds: at 2015 a total balance sheet of TRY 6.741.000, and net annual turnover of TRY 13.478.000. Sworn-in CPA is required to recommend that the error or fraud be corrected in case of discovery of an error or fraud in the financial statements. Tax audits are heavily relied upon by the Revenues Administration (RA) when conducted by Sworn-in CPA. The companies that audited by a Sworn-in CPA are not exempt from tax inspections, there has been no precedent of inspections of such firms to date (World Bank, 2007).

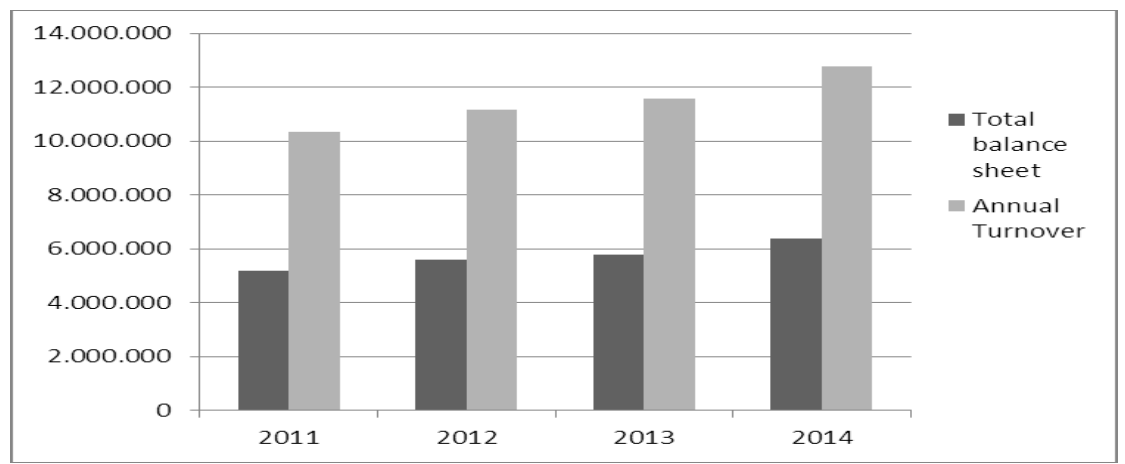

Figure 1: Sworn-in CPA limits (TRY)

An audit which is employed for tax purposes and an audit which is employed for general purpose according to ISA in Turkey have many different aspects and features in particular.

\section{New Auditing Framework of Turkey}

Foundation of the KGK is a precise accomplishment for Turkey especially in the manner of performing of an audit. An audit only can be performed by certificated auditors or audit firms which are approved by the KGK. KGK approves and registers auditors and audit firms. As of November 2016, 14.259 members of the profession (CPAs have 15 years' experience and Sworn-in CPAs) that have 40 hours education certification from universities that approved by KGK have been approved as auditors. The CPAs that have less than 15 years' experience can participate KGK auditor exam.

The KGK gives approval of audit firms with its board decision. As of December 2014, 138 audit firms have been approved and registered by the KGK. 92 of them had already been registered by SPK according to the regulations that were in force before 2012. As of November 2016, there are 220 audit firms.

According to List No: I of the Article 397 KGK's Organization and Responsibilities Decree Law No. 660, the following companies are also subject to statutory audit:

"companies under control of SPK regulations, companies under control of BDDK regulations, insurance, reinsurance and pension companies that are regulated by the law of individual retirement savings and investment plan and law of insurance, institutions authorized by the Istanbul Gold Exchange and allowed to operate as a member; precious 
metals intermediary institutions; joint-stock companies engaged in the production or trade of precious metals, companies licensed for warehousing of agricultural products established as a joint-stock company according to legislation on licensed warehousing of agricultural products, companies established as a joint-stock company in accordance with provisions of the law of public malls and media companies that are owners of national terrestrial satellite and cable television” (Doing Business in Turkey, 2016, para. 3).

In addition above companies, all limited liability companies that meet any two of the following three criteria (issued by Council of Ministries yearly) for two consecutive years are within the scope of mandatory statutory audit, which triggers IFRS application at 2016:

- Total assets: TL 40 million (approximately US\$ 12 million) or more.

- Revenue: TL 80 million (approximately US\$24 million) or more.

- Average number of employees: 200 or more.

"In case of at least two of three criteria mentioned in above decision consecutively exceed their limits in two accounting period, and then the companies will be subject to statutory audit from the subsequent accounting period. As to the determination of whether these criteria are met for current year, the financial statements for last 2 years shall be taken into account regarding total assets and annual net sales revenue. Average number of employees for past 2 years shall be taken into account regarding the number of employees" (Doing Business in Turkey, 2016, para. 5).

That all companies have an annual audit by an independent auditor licensed in accordance with the TAS issued by the KGK. These audits must be carried out in accordance with Turkish Auditing Standards issued by the KGK. Turkish Auditing Standards is based on, and corresponds to, ISA. One of the main objectives of KGK is to set and publish IFRS complied accounting standards.

Total number of audited organizations and companies are given in the below (Capital Market Board of Turkey, 2012; KGK, 2014). In 2013 total 4.186 and in 20145.173 are on statutory audit.

Table 3: Audited Organization and Companies by Years

\begin{tabular}{lrrrrrrrrrrrr}
\hline & 2004 & 2005 & 2006 & 2007 & 2008 & 2009 & 2010 & 2011 & 2012 & 2013 & 2014 & 2015 \\
\hline $\begin{array}{l}\text { Companies under } \\
\text { control of SPK }\end{array}$ & 1193 & 1243 & 1249 & 1293 & 1349 & 1323 & 1537 & 1693 & 1708 & 1686 & 1673 & 1673 \\
$\begin{array}{l}\text { Companies under } \\
\text { KGK regulations }\end{array}$ & - & - & - & - & - & - & - & - & - & 2500 & 3500 & 5000 \\
Total & $\mathbf{1 1 9 3}$ & $\mathbf{1 2 4 3}$ & $\mathbf{1 2 4 9}$ & $\mathbf{1 2 9 3}$ & $\mathbf{1 3 4 9}$ & $\mathbf{1 3 2 3}$ & $\mathbf{1 5 3 7}$ & $\mathbf{1 6 9 3}$ & $\mathbf{1 7 0 8}$ & $\mathbf{4 1 8 6}$ & $\mathbf{5 1 7 3}$ & $\mathbf{6 6 7 3}$ \\
$\begin{array}{l}\text { Independent } \\
\text { Auditing Firms }\end{array}$ & 83 & 91 & 94 & 98 & 97 & 95 & 92 & 92 & 92 & 103 & 138 & 181 \\
\hline
\end{tabular}

Source: Capital Market Board of Turkey, 2012; KGK, 2014

In 2014, statutory audited companies pay $77 \%$ of total corporate tax in Turkey. Until 2016 the number of audited companies will be around 12.000 as a result of Turkey's process of reconciling policy with EU acquis and they will pay $99 \%$ of total corporate tax (Baş, 2014).

The following Figure 2 shows the number of independent auditing firms in Turkey between 2004 -2015. As seen in the figure these companies have increased in recent years. 


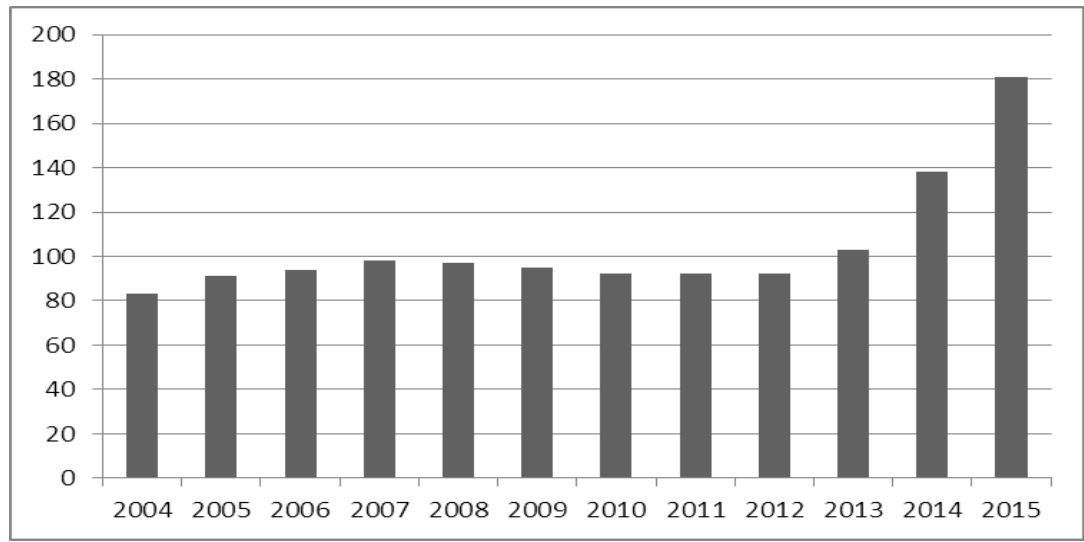

Figure 2: Number of independent auditing firms in Turkey

94.828 Joint Stock Companies has become obligatory audit with TCC published in 2012. This is a kind of limited audit (like International Standard on Review Engagements (ISRE) 2400, "Engagements to Review Financial Statements". Ministry of Customs and Trade is going to prepare an audit communiqué for 94.828 Joint Stock Company and certain cooperatives. They have not prepared the communiqué yet and without the regulations have made joint stock companies unsupervised.

Additionally, there is one more external auditing for corporations is done by Ministry of Costume and Commerce auditors according to the existing by law on the auditing of companies, to verify the accuracy and correctness of the financial statements (Kutlay, 2011). These audits are a new type of external auditing in Turkey that compromise all process of General Assemblies, management boards and transactions including inventory and financial statements at the companies.

For the accounting profession, TCC and TAS are current important topics. In addition, more IFRS and IAS education should be, training should be increased; articles and books should be written for development of accountant and auditors' capacity. Also, "one of the intentions of new Turkish commercial code and Turkish accounting standards is to foster transparency" (K1z1l, Çetin, \& Bulunmaz, 2014, p. 71).

\section{Conclusions}

Auditing has made great strides in the last years in Turkey, but it should develop with the realtime economy.

At Ottoman period there were the auditors in the public sector. The auditing profession began to develop in the last century in Turkey. Regulated by law in 1990 by the accounting profession, the audit profession has begun to develop. This legislation will make the CPA tasks took place between the statutory auditor. CMB list with companies authorized auditors have control these companies. Thus began the exchange Supervision and ISA has been used. Financial statements which are prepared in compliance with IFRS began to be monitored according to ISA rules.

Turkish commercial control area code is further extended with the audit profession. Training of Auditors has become important with the expansion of the scope of the audit. Transitional period of 80 hours of training were carried out by the universities with the approval of UPS. During this 
time, it is not possible to learn the audit process. Therefore, improving the capacities of auditors in Turkey is an extremely important.

In Turkey, TAS is fully complied with IFRSs and Turkish Standards on Auditing have been adopted from ISA. Accounting and auditing professions have a strong relationship with each other all around the world and it is also the fact in Turkey that's why education and training should be increased; articles and books should be written for development of accountant and auditors capacity on the field.

There are significant differences between tax accounting and TAS in Turkey. Audited companies are preparing two separate financial statements. The difference must eliminate in near future.

There are two different independent auditing practices for companies in Turkey, fist is obligatory audit over the Limits of Decision of Ministers and second is limited audit for others Joint Stock Company which is regulated TCC. According the TCC, Ministry of Customs and Trade is going to prepare a communiqué (audit regulation) for the Joint Stock Company that under the limit that audit by CPA/ Sworn -in CPA or certificate auditors. The criteria for this kind of audit are not known yet.

In parallel to the improvements on accounting and auditing in Turkey, there is a strong need to improve the capacity of the accounting and audit profession in order to enhance the quality of audited financial statements and promote public trust. The genuine understanding and adoption of these new accounting and auditing requirements requires related education and training for preparers, auditors, and regulators (KGK, 2014). There must be a greater focus towards the needs of general purpose financial reporting. In this context, enhancing the capacity of existing accountants and future accountants by organizing education and training is highly important.

As a result, in recent years number of accountants and auditing firms in Turkey has been increased according with economic development and with legislation. These problems should be solved for the development of accounting and auditing professions and need to be done academic studies.

\section{References}

A Public Accounting Law. (1927). 1050th Law. Retrieved from www.saglik.gov.tr/TR/dosya/1-46921/h/2115.doc

Arıkan, Y., \& Toraman, C. (2007). The development of the CPA profession in Turkey. Retrieved from www.mufadconference.trakya.edu.tr/conference.prgram.doc

Balsari, C. K., \& Varan, S. (2014). IFRS implementation and studies in Turkey. Accounting and Management Information Systems, 13(2), 373-399.

Baş, S. A. (2014). Bagimsiz denetim [Independet audit]. Retrieved from https://www.cihan.com.tr/tr/kamugozetimi-kurumu-kgk-baskani-seyit-ahmet-bas-1465700.htm

Bell, J. (2014). Turkey’s İșbank secures EBRD funds for SMEs. Retrieved from http://www.txfnews.com/News/Article/3567/Turkeys-bank-secures-EBRD-funds-for-SMEs

Byrnes, P. E., Al-Awadhi, A., Gullvist, B., Brown-Liburd, H., Teeter, R., Warren Jr., J. D., \& Vasarhelyi, M. (2012). Evolution of auditing: From the traditional approach to the future audit. Retrieved from http://www.aicpa.org/interestareas/frc/assuranceadvisoryservices/downloadabledocuments/whitepaper_evol ution-of-auditing.pdf

Capital Markets Board (SPK) of Turkey. (2012).2012 Annual report. Retrieved from http://www.spk.gov.tr/displayfile.aspx?action=displayfile $\&$ pageid=922\&fn=922.pdf \&submenuheader=null

Doing Business in Turkey. (2016). Accounting standards and statutory audit. Retrieved from http://www.doingbusinessinturkey.com/s-accounting_standards_and_statutory_audit-88.html 
Dubravka, P. (2016). History of accountıng and accountancy profession in Great Britain. Journal of Accounting and Management, 6(1), 33-44.

Financial Stability Board. (2014). 2014 IMN survey of national progress in the implementation of G20/FSB recommendations. Retrieved from http://www.financialstabilityboard.org/wpcontent/uploads/Turkey_2014.pdf

Gucenme, G. U., Isseveroglu, G., \& Ertan, Y. (2011). Audit and oversight of audit in terms of commerce law of Turkey. Business and Economics Research Journal, 2(1), 109-120.

Güvemli, O., Aytulun, A., \& Şişman, B. (2012). Türkiye'de muhasebe mesleğinin gelişmesi ve ilk meslek örgütlenmesi: Türkiye muhasebe uzmanları derneği-1942 [The development of accountıng profession in Turkey and the first professional organization: Accounting professionals' association-1942], The Association of Accounting and Financial History Research Journal, 4, 19-49.

IFRS Foundation. (2016). IFRS application around the world jurisdictional profile: Turkey. Retrieved from http://www.ifrs.org/Use-around-the-world/Documents/Jurisdiction-profiles/Turkey-IFRS-Profile.pdf

Investment Support and Promotion Agency of Turkey. (2015). Economic outlook. Retrieved from http://www.invest.gov.tr/en-us/turkey/factsandfigures/pages/economy.aspx

Kamu Gözetimi Kurumu. (2014). Introductory booklet, Ankara. Retrieved from www.kgk.gov.tr

Kızıl, C., Çetin, A. Ç., \& Bulunmaz, A. (2014). Accounting education approach in the context of new Turkish commercial code and Turkish accounting standards. Emerging Market Journal, 4(1), 71-84.

Kutlay, H. (2011). The obligation of independent auditing of corporations under the new Turkish commercial code. Retrieved from http://www.mondaq.com/turkey/x/129696/Audit/The+Obligation+of+Independent+Auditing+of+Corporati ons+under+the+New+Turkish+Commercial+Code

Liu, J. (2015). Study on the auditing theory of socialism with Chinese characteristics. Hoboken, NJ: Wiley.

Matthews, D. (2006). The changing audit process in Britain from the nineteenth century to the present day. New York, NY: Routledge.

Mikol, A. (1993). The evolution of auditing and the independent auditor in France. European Accounting Review, 2(1), 1-16.

Public Disclosure Platform. (2016). General information. Retrieved from https://www.kap.org.tr/en/menucontent/About-PDP/General-Information

Sağlam, N., \& Yolcu, M. (2014). Türkiye denetim standartlarına göre finansal tabloların bă̆ımsız denetimi ve raporlanmasl [Independent auditing of financial statements in accordance with Turkish auditing standards and reporting]. Ankara, Turkey: Yaklaşım.

Teck-Heang, L., \& Azham M. A. (2008). The evolution of auditing: An analysis of the historical development. Journal of Modern Accounting and Auditing, 4(12), 1-8.

The International Auditing. (2016). About IAASB. Retrieved from http://www.ifac.org/auditing-assurance/aboutiaasb

Tomassini, L. A. (1990). The continuing evolution of auditing science: Megatrends and research opportunities for the 1990s. Contemporary Accounting Research, 6(2), 287-294.

TÜRMOB. (2016a). Numbers of profession in Turkey. Retrieved from http://www.turmob.org.tr/TurmobWeb/Kurumsal/UyeIstatistikleri/Istatistik.aspx?param=vXvxwCI6ot/IL1 WTAAXqyo7+IQzWwx2oUZf0ZFm0Q2QIWpk6Ag2NdApm1y4ZbbJGOTnmeQ3qK7L3dgIK6V1HIQ==

TÜRMOB. (2016b). About TESMER. Retrieved from http://www.turmob.org.tr/TurmobWeb/Kurumsal/Tesmer/Hakkinda.aspx

United Nations Conference on Trade and Development. (2012). International accounting and reporting issues. Retrieved from http://unctad.org/en/PublicationsLibrary/diaeed2013d3_en.pdf

World Bank. (2007). Turkey report on the observance of standards and codes (ROSC) accounting and auditing. Retrieved from http://documents.worldbank.org/curated/en/974031468172442987/pdf/662380ROSC00PU04B0Turkey0M arch02007.pdf 